\title{
The Mining Sectors in Chile and Norway, ca. 1870-1940 The Development of a Knowledge Gap
}

\author{
Ranestad, Kristin
}

Document Version

Accepted author manuscript

Published in:

Innovation and Development

DOI:

$10.1080 / 2157930 X .2017 .1322030$

Publication date:

2018

License

Unspecified

Citation for published version (APA):

Ranestad, K. (2018). The Mining Sectors in Chile and Norway, ca. 1870-1940: The Development of a

Knowledge Gap. Innovation and Development, 8(1), 147-165. https://doi.org/10.1080/2157930X.2017.1322030

Link to publication in CBS Research Portal

\section{General rights}

Copyright and moral rights for the publications made accessible in the public portal are retained by the authors and/or other copyright owners and it is a condition of accessing publications that users recognise and abide by the legal requirements associated with these rights.

Take down policy

If you believe that this document breaches copyright please contact us (research.lib@cbs.dk) providing details, and we will remove access to the work immediately and investigate your claim. 


\section{The Mining Sectors in Chile and Norway, ca. 1870-1940: The Development of a Knowledge Gap}

\section{Kristin Ranestad}

Journal article (Accepted version)

Cite: Ranestad, K. (2018). The Mining Sectors in Chile and Norway, ca. 1870-1940: The Development of a Knowledge Gap. Innovation and Development, 81), 147-165. 001: 10.1080/2157930X.2017.132२030

This is an Accepted Manuscript of an article published by Taylor \& Francis in Innovation and

Development on 08 May 2017, available online:

http://www.tandfonline.com/10.1080/2157930X.2017.1322030

Uploaded to CBS Research Portal: January २०19 


\title{
The mining sectors in Chile and Norway, ca. 1870 - 1940: the development of a knowledge gap
}

\begin{abstract}
Chile and Norway are two 'natural resource intensive economies', which have had different development trajectories, yet are closely similar in industrial structure and geophysical conditions. This paper seeks to contribute to the debate about how and why some economies based on natural resource activities have been more dynamic and innovative than others by indicating contributing factors of key differences in one natural resource sector that both countries developed, namely mining. While the Chilean mining sector was considered technologically advanced in the mid-nineteenth century, a technological gap within the sector emerged from the turn of the century, multinationals created enclaves, thousands of mines were abandoned and many of the ore deposits in the country remained unexploited. At the same time, Chile's share of world copper production fell dramatically. The mining sector in Norway, on the other hand, was innovative, multinational companies were more integrated in the host economy and production of large-scale electrometallurgical production started in the late nineteenth century. In an in-depth comparative analysis, I explore how comparable organisations in the two countries - notably universities and mining schools providing formal mining education; organisations aimed to transfer technology and geological research centres developed knowledge and how they help to understand the development gap between the two sectors. The comparison of knowledge organisations shows that more knowledge was developed and accumulated in Norway than in Chile, which indicates that there was a knowledge gap between the two countries. Mining instructions were similar, but there were striking differences between the two countries when it came to 1) number of graduates, 2) number of travel arrangements for practical learning and 3) organised geological mapping and ore surveys. These differences contribute to explain the emerging development gap of the two sectors. The underlying reason for the knowledge gap may be linked to the role of the state. In Norway, the state was much more active in supporting knowledge development through funding of education, scholarship arrangements and the National Geological Survey. In Chile, despite this huge natural resource potential, these key knowledge organisations were given lower priority by the broader set of political decision-makers.
\end{abstract}

Keywords: natural intensive economies; mining; innovation; mining education; technical education; knowledge organisations

\section{Introduction}

Countries rich in natural resources which exhibit poor economic performance, are often understood as being 'cursed' and recommended to shift to industries which are not based on raw materials. A key empirical problem with the 'resource curse' argument is that some of the richest countries in the world, such as Norway, Sweden, Canada and Australia, have developed fastgrowing economies based on natural resources. Differences in economic performance across natural resource intensive economies suggests that an abundance of natural resources does not necessarily lead to stagnation. Conversely, some countries have arguably developed because of their natural resources, not despite them. Evidence suggests that natural resource intensive industries in high-income economies have been highly knowledge intensive, dynamic and innovative, they have created linkages to other industries within the economy, and developed specialisations and new industries which have contributed to complex economic structures (see e.g. Andersen [2012]; De Ferranti et al. [2002]; Ville and Wicken [2013]). I seek to contribute to this special issue about learning and innovation in natural resource intensive industries with a comparison of Chile and Norway, two resource intensive economies which have had markedly different development trajectories, yet are closely similar in structure and geophysical conditions. Norway has developed strongly around natural resource industries such as metal and mineral extraction, timber industries, and fish, and has created a high-income diversified economy. Chile, in contrast, with closely similar resource industries, has failed to experience anything like the same success.

Comparative studies of Scandinavia and Latin America use the similarities in terms of natural resources as the starting point, and argue that certain key factors ensured positive development in the former, while they hindered development in the latter (see De Ferranti et al. 2002; Blomström and Meller 1991 for comparisons). They focus on the use of foreign technology, agricultural reforms, political regulations and education systems. This comparative approach is 
valuable, however the discussion remains general. Few of the factors are discussed in detail and little empirical evidence is provided to support the arguments. We still have little knowledge of why some natural resource industries have been more innovative than others.

I seek to add to this comparative study literature by comparing knowledge development indepth in one natural resource sector, namely mining. Comparing one sector, instead of the whole economy, allows for more detailed empirical analyses of learning and innovation processes. Indepth comparisons give important insight into similarities and differences and are useful to further our understanding of how natural resource industries in some countries have become highly innovative, while they have been less innovative in others. Based on the argument that learning depends on an innovation-friendly institutional and organisational context, I compare the performances of comparable knowledge organisations which aimed to develop technological knowledge for mining in Chile and Norway.

The period from 1870 to 1940 is chosen because world mining went through important technological changes during these years and allows to ask how Chile and Norway coped in a situation of technological turbulence. To continue rational operation, new energy sources were brought into use. Additionally, the work organisation and the techniques for finding, removing and processing ores changed radically. This was also the period in which the two countries started to diverge economically. The two countries had comparable economic growth until the 1930s. Thereafter, an economic gap began emerging from the late 1940s, and Norway, some say against all odds, developed to become one of the richest countries in the world with a literate population from a very early stage and small social differences. Chile, on the other hand, had high illiteracy rates until the mid-twentieth century, has until recent decades had slow economic growth and still has poverty and large social differences. Although we cannot fully answer the determinants of success and failure in Chile and Norway, I believe this paper points out some important factors which contributed to a development gap between the two mining sectors, which adds to our understanding of the different economic performances of the two countries.

\section{The historical contexts of the two mining sectors: a gap in development}

Mining has historically been the most important economic sector in Chile. Thousands of big and small companies have formed the sector and in the late nineteenth century mineral and metal products represented up to ninety per cent of export (Braun et al. 2000, 165-167). The country became extremely dependent on this sector. The size of it made its development particularly important and the challenges it faced, equally severe. The lack of innovation and advance prevented the sector from stimulating strong growth and becoming a real driving force of the economy. In Norway, the mining sector was smaller, but increased from 6, 5 per cent of exports in 1900 to 29, 2 per cent in 1939 (SSB 1952, 1953). The mining sector was one of many export sectors, which made the Norwegian economy less dependent on one export product and in turn less vulnerable. These differences are important to consider when comparing differences in economic performances of the two countries.

A gap began emerging between the smaller mining sector in Norway and the large Chilean sector from the late nineteenth century. While the Chilean mining sector was considered technologically advanced in the mid-nineteenth century, from the turn of the century, some repeated traits suggests an overall more negative development in Chile and a more positive development in Norway. The two sectors differed mainly in three aspects, namely (1) the relative extent to which mineral ores were utilised; (2) the technological level of the sector and (3) the extent to which multinationals were integrated in the host economy.

Perhaps the most remarkable negative trait in Chile was the thousands of mines that were abandoned and the large unutilised mineral and metal ores. Chile had, and still has today, much natural resource potential, in terms of hydroelectric capacity and deposits of iron, silver, gold, sulphate, zinc, manganese and some of the world's largest deposits of copper (Gandarillas Matta 1915; SNM 1890-1940). This potential was not taken advantage of (Gandarillas Matta 1915; Macchiavello Varas 2010). In Norway, in contrast, in addition to traditional metals, such as copper, 
silver, iron and nickel, large-scale mineral and metal productions were initiated in the late nineteenth century, in addition to a new electro-metallurgical industry based on the utilisation of hydroelectric power (Carstens 2000).

The technological level of the two sectors began to diverge from the late nineteenth century. In Chile, high-grade copper ores were exhausted and only lower grade copper deposits of under four percent copper remained. In the early twentieth century, North American companies began to exploit some of these low-grade copper ore deposits, using up-to-date technology including mechanised equipment, large electric power plants and electrolysis. Small-scale Chilean companies, in contrast, used old and inefficient technology based on human and animal power and 'pirquen' work ${ }^{1}$ and produced less pure minerals and metals. Disorganised and inefficient working methods without technical and economic order led to disorderly developed mines, which were often torn down. This resulted in huge mineral losses (Villalobos 1990, 97-101). This technological gap between multinationals and Chilean mining companies, was accompanied by a dramatic fall in copper production. Until 1880s, Chile was the world's largest copper producer, but in 1910 the country stood for only 4 percent (OCEa 1911). Moreover, the saltpetre industry which increased in the late nineteenth century was "... a sinking ship" after WWI (see e.g. Soto Cardenas [1998]; Villalobos [1990]; Macchiavello Varas [2010]; Mamalakis [1976]; Wilkins [1974]) for descriptions of the challenges in the mining sector). In Norway, on the other hand, there was no clear technological gap between multinationals and Norwegian companies. Norwegian companies, such as Kongsberg silverworks and Røros copperworks, were often ahead of multinationals in the use of new technology (Carstens 2000; Børresen 2007).

Multinationals operated differently in the two countries. In Chile, large-scale North American copper companies created 'enclaves' from the early twentieth century and the few linkages that had developed between suppliers in the country and these mining companies in the nineteenth century, declined, and disappeared from the 1920s. Mechanical workshops normally offered steam locomotives and simple equipment instead of complex machinery, power plants and furnaces, which gave the multinationals no other option than to purchase technology from other countries (Carmagnani 1998, 88). Moreover, multinational saltpetre and copper companies exclusively used foreign engineers and other skilled workers in managing and strategic technical positions. Their control over some of the country's key natural resources made their negative effects particularly damaging for the Chilean economy. In Norway, multinational companies also dominated the mining sector. However, they were altogether more integrated in the economy in that they used mechanical workshops in the country for inputs and hired engineers and other skilled workers from Norway to strategic technical and managing positions and Board of directors. Moreover, Norwegian engineers were heavily involved in the start-up of many of the multinational mining companies (see Ranestad, "Multinational").

The turn of the century was clearly a period in which the mining sector in Chile fell behind. The gap was challenging to fill and as Reich argues: "(O)nce off the technological escalator it's difficult to get back on" (taken from Cohen and Levinthal 1990, 136-137). This was, thus, a turning point in the history of Chilean mining. In the next sections I present an empirical comparative analysis of comparable knowledge organisations in the two countries with similar aims, but which, I argue, performed differently and contribute to explain the development gap between the two sectors.

\section{Methodology: empirical comparative approach}

To understand how and why certain countries and industries are more innovative than others, some economic historians analyse in detail how knowledge development occurred and how learning was transformed into technological innovation (see for example Mokyr 2005; Bruland 1998; Bruland and Smith 2010; O'Brien 2011). Drawing on these approaches, I explore empirically how knowledge was accumulated in the two countries. An important observation at this point is that

\footnotetext{
${ }^{1}$ Miners collecting minerals and paying a fixed price or parts of the outcome to the owner.
} 
similar types of public and private mining organisations (organisations defined as actors bound together by a common purpose, North [1991]), which aimed to develop scientific and technological knowledge, were developed in both countries in the nineteenth and early twentieth centuries:

(1) Universities and mining schools providing intermediate and higher mining engineering programs

(2) Scientific and technical societies (publishing technical magazines and organising industrial exhibitions)

(3) Funds providing scholarships for study travels

(4) Establishments carrying out geological surveys

The formation of these organisations suggests an ambition in both Chile and Norway to advance the mining sectors. However, we need to analyse the regulations and norms regulating these organisations (defined by North as 'institutions' [1991]) in further detail, i.e. how these establishments performed, and their effects on innovation.

The empirical analysis is based on primary sources from archives in Chile, Norway and the United States, and divided into two main parts. First, I make a framework of how technologically up-to-date mining companies in Chile and Norway operated around the turn of the twentieth century. This includes: (1) making a model of the types of knowledge that was used, and developed, to carry out the mining and extraction of metals and minerals. Knowledge terms, notably natural sciences, 'tacit' knowledge, 'know-what', 'know-how', 'know-who' and 'knowwhy' are used to detect different aspects of knowledge involved in innovation processes, and (2) presenting the organisations which often interacted with mining companies in innovation processes. These two models do not claim to present rigid and linear systems of knowledge development and innovation, but rather include key knowledge aspects and organisations involved repeatedly in the development of innovative, dynamic and technologically advanced mining projects.

Second, with these models as a starting point, I compare knowledge development in Chile and Norway by analysing the performance of key knowledge organisations; universities, mining schools, establishments which aimed to transfer technology and geological research centres. By analysing similarities and differences of comparable variables in history, the aim here is to "... circle in on" the factors that might explain the development gap of the two sectors. The variables I look at are:

i) Formal mining instruction: study programs and course descriptions exist for both countries on intermediate and higher level and are used to compare the content of the formal mining education.

ii) Number of mining engineer and technician graduates: the number of mining engineer graduates per year are known for both countries. The number of workers per mining engineer is calculated based on the supposition that the average career in mining was forty years. In the case of mining technicians, we have the number of graduates for Norway and for Chile we do not have the total number of graduates for the whole period, but from all mining schools from 1905 to 1925 . Therefore, it is not possible to make the same estimate and comparison as for mining engineers, but we can still make some indications.

iii) Organisations for knowledge transfer (technical magazines, industrial exhibitions and scholarships for study travels and learning): student yearbooks from Norway provide unique information about the work, positions and travels of all the mining engineer-, technician- and other graduates who worked in the mining sector (see Ranestad [2015] for an explanation of these sources). From Chile, we have information about seventythree of the 302 mining engineers who graduated between 1850 and 1940 and 192 of the mining technicians. These sources, together with engineering and company reports and technical and mining journals, makes it possible to follow the graduates from 
school and into their working life, and they enable an in-depth comparison of the relationship between knowledge development, education, learning and innovation.

iv) Geological research centres: mining journals, engineering reports and secondary literature are used to make a comparison of the organised geological mapping and ore surveys for both countries.

The main questions I ask are: why did the mining sectors in Chile and Norway develop differently in terms of (1) the relative extent to which mineral ores were utilised; (2) the technological level of the sector and (3) the extent to which multinationals were integrated in the host economy? I explore these questions by looking to similar organisations which aimed to develop knowledge for mining. The aim is to further our understanding of 1) the performances of these organisations in Chile and Norway, and 2) how they may contribute to explain the innovative sector in Norway and the less innovative sector in Chile.

\section{Setting a framework for mining: catching up with new and complex technology}

From the late nineteenth century, mining worldwide faced major challenges, due to a gradual exhaustion of high-grade ores and the extraction of new metals and minerals. Maintaining profitability in new global settings involved adopting new techniques to find ores, for ore prospecting, removing ore, organisation of work and ore processing. More powerful machinery and power sources became common as mechanical and electrical power largely replaced steam, animal and manual power, which in turn enabled deeper mines and larger production. New converters, furnaces, ore dressing- and smelting techniques permitted the utilisation of lower grade ores (for general technological development in mining see Singer et al. [1958a; 1958b).

As these changes occurred, the knowledge that was used in technologically up-to-date mining became increasingly specialised. Constructions and structures beneath the earth was particularly difficult, since the mines could easily collapse. As mining developed, intricate mathematical calculations were essential to make deep, large and sustainable mines and knowledge of geometry, geology, physics, construction engineering and skills in precision were used to design and make tunnels, adits, shafts, install lifting devices and make ventilation systems (see table 1). Modern technologically advanced large-scale mining companies became gradually more dependent on mining engineers and technicians to manage and administrate operation efficiently and to operate complex technology (Børresen 2007; Musgrave 1967; Macchiavello Varas 2010). Skilled workers with other educational backgrounds, such as electro-engineers, mechanical engineers, chemists, economists etc. also became indispensable, as mining constructions increasingly multifaceted and new chemical and electro-metallurgical techniques developed (Musgrave 1967).

At the same time, much learning happened through practice, which suggests a large degree of 'tacit knowledge' in all mining activities (Mokyr 2006). This was related to the 'local specificity' (Andersen et al. 2015, 48-49) and the particular geological conditions which characterised each mine and processing plant when it came to size and the composition of the ore being extracted.

To maintain profitability, companies had to keep themselves continuously informed about new and more efficient technology. Furthermore, to enable successful adoption of new technology, companies acquired in-depth knowledge of how to transfer, modify, use and repair the machinery, equipment and techniques. The knowledge categorisation made by Bengt-Åke Lundvall; 'knowwhat', 'know-who', 'know-how' and 'know-why', capture the broad set of knowledges that were involved in technology transfer processes. Know-what is defined as the factual information about the technology; know-who is the knowledge about who the relevant people are for the solution of problems; know-how is the ability, practical skills and capabilities to do something and know-why is the scientific and technological principles for the solution of problems (see Lundvall [2010], 330). Together, these knowledge elements enabled successful transfer and adoption of technology. 
In sum, technologically complex and innovative mining projects used a broad spectre of knowledges. Table 1 sums up the knowledge areas that were used in the three main steps of the making of mineral and metal products:

Table 1.Simple overview of knowledge used in technologically advanced mining

\begin{tabular}{|c|c|c|c|c|}
\hline $\begin{array}{c}\text { Steps in the mining } \\
\text { process }\end{array}$ & Knowledge areas & $\begin{array}{l}\text { New knowledge } \\
\text { areas from the late } \\
\text { nineteenth century }\end{array}$ & $\begin{array}{c}\text { Tacit } \\
\text { knowledge }\end{array}$ & $\begin{array}{c}\text { Transfer of } \\
\text { new } \\
\text { machinery, } \\
\text { equipment, } \\
\text { convertors, } \\
\text { furnaces etc. }\end{array}$ \\
\hline $\begin{array}{l}\text { 1.Geological } \\
\text { surveys/prospecting }\end{array}$ & $\begin{array}{l}\text { Geology } \\
\text { Mineralogy } \\
\text { Chemistry } \\
\text { Economics }\end{array}$ & \multirow{3}{*}{$\begin{array}{l}\text { Electro-engineering } \\
\text { Economics } \\
\text { Administration }\end{array}$} & \multirow{3}{*}{ High degree } & \multirow{3}{*}{$\begin{array}{l}\text { Continuous } \\
\text { acquisition of: } \\
\text { know-how } \\
\text { know-what } \\
\text { know-who } \\
\text { know-why }\end{array}$} \\
\hline 2.Removal of ores & $\begin{array}{l}\text { Physics } \\
\text { Mathematics } \\
\text { Construction- } \\
\text { engineering } \\
\text { Mechanics }\end{array}$ & & & \\
\hline 3.Processing of ores & $\begin{array}{l}\text { Geology } \\
\text { Mechanics } \\
\text { Chemistry } \\
\text { Mineralogy } \\
\text { Metallurgy } \\
\text { (electro- } \\
\text { engineering, } \\
\text { electro-chemistry } \\
\text { etc.) }\end{array}$ & & & \\
\hline
\end{tabular}

Sources: Based on Ranestad (2015, 151-197)

The start-up and advance of innovative mining companies depended on a whole set of interacting and collaborating organisations, in the country and abroad, which accumulated knowledge and developed technological capabilities. Table 2 shows organisations which provided companies with information, machinery, equipment, skilled workers and expertise.

An important channel of information (know-what) was technical magazines and mining journals, normally published by technical and scientific societies. Their function was to spread information and publish updates about new technology and patents. International exhibitions were also important sources of information about new mining machinery, power sources, drillinglifting- and transport equipment, converters, furnaces, turbines etc. on the market.

When adopting a new machine, furnace or equipment, mining companies bought services and supplies from mechanical workshops and often consulted other firms, either in the country or abroad, where the technique was already in use. Educational establishments, in turn, provided trained workers and chemical experiments and new separation-, concentration- and smelting techniques were often developed in laboratories.

Geological maps, prospecting and detailed scientific ore analyses were vital to begin and maintain efficient and profitable mining projects. Without a deep understanding of the existing mineral and metal deposits and their potential profits, new mining projects could hardly take place and the mining sector could barely advance (David and Wright 1997). In this context, countries began creating national geological survey organisations during the nineteenth century to make systematic and detailed geological maps and ore analyses of the nations' resources. The utilisation of gradually lower grade mineral and metal ores from the late nineteenth century, increased the importance of detailed information about possible economic returns. Table 2 presents activities and organisations which were often involved in innovation processes at the turn of the century: 
Table 2.Simplified model of organisations collaborating with mining companies in innovation processes

\begin{tabular}{|l|l|}
\hline \multicolumn{1}{|c|}{ Innovation activity } & \multicolumn{1}{c|}{ Collaborating organisations and their functions } \\
\hline $\begin{array}{l}\text { Finding and analysing mineral and metal } \\
\text { ores }\end{array}$ & $\begin{array}{l}\text { Geological surveys: public or private organisations made } \\
\text { geological maps and ore surveys }\end{array}$ \\
\hline Being informed about new technology & $\begin{array}{l}\text { Technical and scientific societies: distributed technical } \\
\text { magazines and organised industrial exhibitions with } \\
\text { information about new technology }\end{array}$ \\
\hline $\begin{array}{l}\text { Creating, transferring and installing more } \\
\text { efficient equipment, furnaces, machinery etc. }\end{array}$ & $\begin{array}{l}\text { External companies (in the country or abroad): mechanical } \\
\text { workshops and mining companies producing and using } \\
\text { relevant techniques provided supplies, services and expertise. }\end{array}$ \\
& $\begin{array}{l}\text { Research establishments (in the country or abroad): } \\
\text { laboratories, universities and research centres shared their } \\
\text { research and offered consultant work }\end{array}$ \\
\hline Using new technology & $\begin{array}{l}\text { Universities, technical and mining schools (in the country or } \\
\text { abroad): provided formally trained graduates with relevant } \\
\text { scientific and practical knowledge }\end{array}$ \\
\hline
\end{tabular}

Source: Based on Ranestad (2015, 151-197)

It should be stressed that other factors were required to develop profitable mining companies. Capital, investments, markets, prices etc. of course influenced productions and industrial development. However, the different knowledge aspects outlined here, and the organisations which supported the development of these, formed a setting that was indispensable to innovate, catch up to up-to-date mining and carry out efficient and successful mining.

\section{Comparative empirical analyses of knowledge organisations for mining in Chile and Norway}

\section{a. Mining instruction}

In 1757, the Mining Seminar in Kongsberg in Norway was established. Later, in 1814, the mining engineering program was transferred to the Royal Frederick University in Christiania and in 1914 it was again transferred to the newly opened Norwegian Institute of Technology (NIT). In 1867, the Ministry of Finance opened an intermediate mining school, Kongsberg Silver Works Elementary Mining School. In Chile, the Faculty of Mathematics and Physical Science provided education in mining engineering from 1853. Additionally, public intermediate mining schools were established at some of the important mining districts around the country. The Mining School of Copiapó was founded in 1857; the two mining schools of La Serena and Santiago were founded in 1887, but the Mining School of Santiago was closed in 1912. The Industrial School of Saltpetre and Mining in Antofagasta, was founded in 1918. In both countries, the mining engineering program represented a long study (4-6 years) and was theoretically and scientifically oriented, while mining technician programs were shorter and more focused on practical exercises and work.

The content of the study programs was remarkably similar in the two countries. They included general natural science courses as well as courses which were directed towards specific tasks in mining. The foundation of the mining engineering programs were natural science courses, notably mathematics, physics, mechanics, geology, chemistry and mineralogy, in addition to mining subjects, such as the use and repair of mining machinery, courses about mine structures and constructions, metallurgy, ore survey etc. The knowledge areas, on which mining activities were built, outlined in table 1, roughly matched the mining engineering programs in both countries (see table below):

Table 3. Simple overview of knowledge domains and mining engineering study programs

\begin{tabular}{|l|l|l|l|l|}
\hline \multicolumn{1}{|c|}{ Knowledge areas } & \multicolumn{2}{c|}{ Mining instruction in Chile } & \multicolumn{2}{c|}{ Mining instruction in Norway } \\
\hline Mathematics & $\begin{array}{l}\text { Continuous } \\
\text { courses: }\end{array}$ & $\begin{array}{l}\text { New courses (first } \\
\text { adopted): }\end{array}$ & $\begin{array}{l}\text { Continuous } \\
\text { courses: }\end{array}$ & $\begin{array}{l}\text { New courses (first } \\
\text { adopted): }\end{array}$ \\
$\begin{array}{l}\text { Physics/mechanics } \\
\text { Geology }\end{array}$ & Mathematics & Drawing: 1889 & Mathematics & Study of machines: 1871 \\
Mineralogy & Mechanics & & Mechanics & Electro engineering: 1909 \\
\hline
\end{tabular}




\begin{tabular}{|c|c|c|c|c|}
\hline $\begin{array}{l}\text { Chemistry } \\
\text { Metallurgy (electro-engineering, } \\
\text { magnetism etc.) } \\
\text { Construction engineering } \\
\text { Electro-engineering }\end{array}$ & $\begin{array}{l}\text { Geology } \\
\text { Mineralogy } \\
\text { Chemistry } \\
\text { (metallurgy) } \\
\text { Ore testing } \\
\text { Ore surveys } \\
\text { Mine measuring } \\
\text { Utilisation of } \\
\text { mines }\end{array}$ & $\begin{array}{l}\text { Machines (specially } \\
\text { applied to mines): } 1889 \\
\text { Construction: } 1889 \\
\text { Political economy and } \\
\text { administrative law: } 1889 \\
\text { Electro engineering: } 1908\end{array}$ & $\begin{array}{l}\text { Geology } \\
\text { Mineralogy } \\
\text { Mining construction } \\
\text { Mine factory } \\
\text { Metallurgy (ore } \\
\text { treatment and } \\
\text { analyses) } \\
\text { Machine drawing }\end{array}$ & $\begin{array}{l}\text { House construction: } 1911 \\
\text { Social economics and law: } \\
1911\end{array}$ \\
\hline
\end{tabular}

Sources: Based on Ranestad (2015, 256-314)

Instructions in both countries combined theoretical learning, learning by observing and learning by doing by mixing different teaching forms:

(1) Lectures in classrooms

(2) Practical exercises, such as drawing and laboratory work

(3) Geological excursions and visits to companies and plants

(4) Working practice at mining companies

The mining technician programs included similar courses as the mining engineering programs in both countries, but excluded in-depth teaching of scientific theories and focused instead more on hands-on practice and exercises (SB 1966; EMC 1957)

Changes were made continuously in the study programs in both countries. Changes and adoption of new courses happened normally after new technology had been adopted and spread throughout the sector. For instance, new courses in mining machinery were introduced in the programs after a mechanisation process and electro-engineering, which was introduced as new courses both places in the early twentieth century, occurred after the shift to electric power around the turn of the century. Specialisations were gradually made in the mining engineering programs from the turn of the century, with one program focusing on mining and the other on metallurgy (NIT 1932; UC 1890). These changes responded to the increasing mining specialisations that occurred in the two countries, and globally, at the time. Old laboratories and workshops were gradually upgraded in both countries and new and improved teaching facilities were constructed. Moreover, both countries used professors from different countries, both domestic and European, which indicates teachers with varied experience (Domeyko 1872).

In sum, the study programs adapted to and supported the increasingly technologically complex mining projects that characterised world mining at the time. The educational establishments in both countries offered highly relevant mining instructions and provided graduates with similar scientific and practical training. Therefore, there is reason to believe that other knowledge factors instead explain how and why the two sectors developed so differently.

\section{b. Number of mining engineer and technician graduates}

A clear distinction between the two countries was the number of mining engineer and technician graduates available in the country compared to the size of the two sectors. From 1850 to 1940 the total number of graduated mining engineers in Norway was 287 (AMS 1855-1940), while it totalled 302 in Chile (UC 2003). Both countries had a steady provision of mining engineers, but given that the mining sector in Chile was tenfold larger than the sector in Norway in terms of number of workers and companies, productions and exports, the mining sector in Chile, with only an additional 15, had access to much fewer mining engineers. This can be shown by simple estimates. Taking the whole sectors as a starting point, if mining engineers had an average career of forty years, the number of workers per mining engineer remained relatively stable between 45 and 92 in Norway, while the relative number of mining engineers declined in Chile; in 1885, there were 394 workers per mining engineers, in 1925 there were 1395, and in 1940755 workers (see table below):

Table 4. Workers per mining engineer (selected years) Estimated career of 40 years

\begin{tabular}{|c|c|cc} 
Year & Norway & Chile
\end{tabular}




\begin{tabular}{|c|c|c|c|c|c|c|c|c|}
\hline & Workers & $\begin{array}{l}\text { Number of } \\
\text { mining } \\
\text { engineer } \\
\text { graduates* }\end{array}$ & $\begin{array}{c}\text { Estimated } \\
\text { number of } \\
\text { mining } \\
\text { engineers } \\
\text { available } \\
\end{array}$ & $\begin{array}{c}\text { Number of } \\
\text { workers per } \\
\text { mining engineer }\end{array}$ & Workers & $\begin{array}{l}\text { Number of } \\
\text { mining } \\
\text { engineer } \\
\text { graduates* }\end{array}$ & $\begin{array}{c}\text { Estimated } \\
\text { number of } \\
\text { mining } \\
\text { engineers } \\
\text { available } \\
\end{array}$ & $\begin{array}{c}\text { Number of } \\
\text { workers per } \\
\text { mining engineer }\end{array}$ \\
\hline 1860 & -- & 3 & -- & -- & 21367 & 4 & 15 & 1424 \\
\hline 1865 & $\begin{array}{ll}3408 \text { (year } \\
1866)\end{array}$ & 1 & 48 & 71 & 24396 & 0 & 27 & 903 \\
\hline 1870 & 3239 & 1 & 50 & 65 & 27033 & 7 & 49 & 552 \\
\hline 1875 & 2978 & 0 & 49 & 61 & 30207 & 9 & 69 & 438 \\
\hline 1880 & 2240 & 3 & 50 & 45 & 37935 & 4 & 94 & 404 \\
\hline 1885 & 2383 & 0 & 51 & 47 & 43789 & 2 & 111 & 394 \\
\hline 1890 & 2899 & 2 & 45 & 64 & 51345 & 2 & 122 & 421 \\
\hline 1895 & 2015 & 3 & 51 & 40 & 59713 & 1 & 129 & 463 \\
\hline 1900 & 3319 & 1 & 49 & 68 & 55398 & 2 & 124 & 447 \\
\hline 1905 & 4768 & 3 & 52 & 92 & 66626 & 3 & 122 & 546 \\
\hline 1910 & 6652 & 12 & 91 & 73 & 83677 & 0 & 104 & 805 \\
\hline 1915 & 8917 & 6 & 152 & 59 & 95421 & 3 & 91 & 1049 \\
\hline 1920 & 6267 & 6 & 179 & 35 & 98442 & 3 & 86 & 1145 \\
\hline 1925 & 8427 & 3 & 198 & 43 & 131168 & 8 & 94 & 1395 \\
\hline 1930 & 9727 & 2 & 191 & 51 & 127882 & 7 & 103 & 1242 \\
\hline 1935 & 9597 & 5 & 197 & 49 & 99344 & 12 & 130 & 764 \\
\hline 1940 & 10074 & 1 & 221 & 46 & 123065 & 10 & 163 & 755 \\
\hline
\end{tabular}

Calculated based on the number of mining engineer graduates and total workers in the sector.

Source: Ranestad (2015, 314-54).

*Number of graduates the current year.

Chile would have required hundreds, and some years, thousands of more mining engineer graduates to match Norway. One of the large-scale copper company, Braden Copper Company, alone required around 90 mining engineer graduates to reach 100 workers per mining engineer. However, in the period in which the three large North American copper companies were established, between 1904 and 1923, there were normally less than a hundred mining engineers available for the whole mining sector. In 1880, instead of 94, Chile would have needed 800 available mining engineers to reach 45 workers per mining engineer, as in Norway. In 1920, Chile would have required 2800 mining engineers to obtain 35 workers per mining engineer, instead of the available 86. It was undoubtedly highly challenging for this small amount of mining engineers to fill thousands of positions at the mining schools, research establishments and the thousands of companies in the country.

In Norway, 191 mining technicians graduated from Kongsberg Silver Works Elementary Mining School between 1869 and 1940 (SB 1966). There were in total fewer mining technicians than mining engineers, but with similar estimates as for the mining engineers, workers per mining technician always remained under ninety. In Chile, the total number of graduates from all mining schools between 1905 and 1925 totalled 415 graduates. The available numbers indicate that the provision of mining technicians was considerably higher than mining engineers. 1906 represents the year with the most mining technician graduates, with forty-five graduates. In 1925, the number had decreased to thirteen (OCEb 1905-1925). Nevertheless, despite a higher number of mining technicians, there were also few of them considering that the number of workers in the sector were sometimes over 100000 workers.

In Norway, mining engineers and technicians, as well as other skilled workers, such as chemists, construction engineers, mechanical engineers, electricians, and workers with administrative background, such as economists, accountants and secretaries, were continuously recruited to the mining sector (AMS 1855-1940; Bassøe 1961). Skilled workers switched jobs between multinationals and Norwegian companies, which enabled a spread of experience and know-how between them.

In Chile, in contrast, engineers, company managers, professors and other members of the National Mining Society in Chile explicitly requested more trained workers, especially mining engineers (see all years SNM 1890-1940). Civil engineers and mining technicians functioned as relatively good substitutes for the mining engineers, but also they were scarce (SNM 1925, 6634). The technologically backward small-scale companies normally did not employ engineers or other skilled workers. Directors and managers were without training and lower positions were 
filled by 'simple practitioners' without technical instruction and in many cases without primary school (SNM 1910, 330). The fact that skilled workers were absent at these companies is perhaps an indication that they were redundant. However, if the small-scale companies were to rationalise, adopt new energy sources, machinery and processing techniques, mining engineers and workers with relevant scientific and practical experience to manage this technology, were key. The problem was that, even if these companies intended to innovate, the University and mining schools provided too few graduates for them to recruit and to advance the sector.

The foreign technologically advanced companies had an alternative, namely to hire foreigners. They recruited hundreds of engineers, as well as technicians, mechanics, chemists, electricians etc. from abroad (Solano Vega 1918; ACMCR 1925-1928 staff). As seen, foreign engineers almost exclusively held the managing and strategic technical positions at these companies. The absence of Chilean mining engineers prevented them from learning about efficient ways of organising and managing large-scale production and operating up-to-date complex mining technology which was used at the multinationals. This, in turn, blocked potential transfer of technical and managerial knowledge from the multinationals, which the inefficient small-scale companies clearly would have benefitted from (see Ranestad, "Multinational").

Why were there relatively more mining engineers, technicians and skilled workers in Norway than in Chile? This was probably related to a social problem of limited basic education. The government in Chile consisted of a minority from the oligarchic political elite, in a large degree agrarian and mercantile, which did not see the value of an educated working class (Egaña Baraona 2000). In 1920, more than a century after independence, obligatory primary education was introduced. As late as the 1950s, approximately nine per cent of the school age population never attended school. Thirty per cent of those who entered the first grade abandoned school within the first two years and only 28,6 per cent of the school age population completed their primary education. In 1960, only about 20 per cent of a given age cohort entered secondary education. Moreover, only one half, or fewer, of the high school graduates succeeded in passing the final high school exam (Blitz 1965, 305-306). A large share of the population in Chile was illiterate up until recent decades. In 1865 only eighteen per cent of the population was literate, which increased to 30,3 per cent in 1885 (Engerman and Sokoloff 2005). In 195019,8 per cent of the population was still illiterate (Blomström and Meller 1997, 7). The lack of formal education and high illiteracy had two negative consequences. First, the large share of unskilled mining workers prevented knowledge diffusion on a lower level. The director of one of the mining schools in Chile found that mining projects would fail due to "lack of a conscious, rational and scientific direction" (SNM, 1926, 644-646). This was largely what happened to the disorganised and inefficient small-scale companies. Second, this created a bottleneck in the education system, which blocked the recruitment of students to the University, technical schools, the Mining Schools and especially to the mining engineering program, since to be accepted, the students needed to have finished secondary school and to pass an admission test.

In Norway, in contrast, campaigns to improve the reading and writing skills of the population have roots back to the seventeenth century. During the nineteenth century, the government gradually increased public funds to education (Hodne and Grytten 2000, 151). From 1827 , all children in the country between seven and fourteen years old were to receive teaching in reading, writing and some calculation. In 1860, a law was introduced, which established a school system with regular school for all during seven years. The development of the basic school system was accompanied by a near to a hundred percent literacy estimate rate by the 1890 s (O'Rourke and Williamsen 1995, 299), which assured skilled mining workers and a supply of relatively many more qualified students to the engineering and technician programs.

\section{c. Organisations for knowledge transfer}

Efforts were made in both Chile and Norway to transfer knowledge from other countries to the mining sector. Technical magazines with information about up-to-date mining technology was published in both countries and facilitated access to 'know-what' (DNIF and DPF 1913-1940; 
SNM 1890-1940). Additionally, engineers and workers participated at industrial exhibitions (AMS 1855-1940; SNM 1890, 96; Yunge 1905). Thus, having information about new technology was not the aspect that separated Chile and Norway.

But it was not enough to read about new machines and equipment in magazines or observe them at exhibitions. Selecting, transferring, using, repairing and maintaining mining- and processing techniques successfully, required long hands-on experience, as well as thorough knowledge of local conditions. Visits to foreign mining plants, research centres and universities where relevant technology was used, were therefore key. During trips abroad, engineers and technicians acquired valuable know-who and most importantly they acquired practical know-how and know-why of technology which might be useful at home. Professors and engineers in both Chile and Norway expressed the importance of such trips and the establishment of travel funds for such purposes (Domeyko 1872, 22; TU 1883, 133-4).

Yet, differences between the two countries appear when taking a closer look at the initiatives that were made to support foreign travels and practical learning. Continuous public and private programs for travel scholarships were established in Norway. Ninety-nine scholarships, grants and funds were provided to mining engineers between 1850 and 1940 with the aim of learning about mining technology. Over seventy per cent of the mining engineer graduates went abroad to visit plants and industrial exhibitions, do practice, work for a longer period at a foreign company or to do field trips (AMS 1855-1940; Bassøe 1961). In Chile, in contrast, there are traces of only six public and private scholarship arrangements. There are no traces of mining engineers systematically going abroad, as the Norwegians did from an early stage (Jerez Bravo 1950; UC 1843-1940; SNM 1890-1940).

What did these differences mean? Few travels abroad meant that the mining engineers from Chile had fewer contacts and much less hands-on experience with up-to-date technology compared to the engineers from Norway, which put them in a disadvantage. The small number of scholarships for travelling purposes hindered a free flow of practical knowledge to the mining sector in Chile - a sector which certainly would have benefitted from know-how about new and efficient technology. Without extensive accumulation of such hands-on experience, innovating was extremely difficult.

Why were there so few travel arrangements in Chile? Engineers, professors and politicians clearly saw the importance of them. Lack of language skills may have prevented engineers from going abroad, but this was also a challenge for the Norwegian engineers. Was Chile too far away from industrial powers? Norway was situated in Europe, and much closer to Germany, England and France than Chile, which made it easier, cheaper and faster for people to travel. On the other hand, many Norwegians travelled to the United States, Chile, South Africa and Australia, which also implied long and complicated travels. If the only problem was travelling distance, this challenge has been overcome many times in history. Even though knowledge transfers were valued, supporting foreign travels and work experience in other countries seem to have been given lower priority by the broader set of political decision-makers.

\section{d. Geological mapping and ore surveys}

The most remarkable difference between the two sectors was related to initiatives to organise detailed geological mapping, prospecting, analyses of ore and economic planning. In Norway, the Geological Survey of Norway, a public organisation, was established in 1858. The Survey had two main tasks. First, it sought to contribute with new knowledge about geological features, their scope and potential utility. Second, it was to contribute to new and more systematic surveys of the country's geological formations and deposits. Extensive geological mapping and prospecting of regions which were rich in minerals led to publication series about Norwegian geology, maps and ore prospecting analyses. Gradually more detailed maps were made during the late nineteenth century and early twentieth century (Børresen and Wale, 2008, 96).

Chile lacked geological surveys and analyses of the country's metal and mineral deposits. A permanent organisation with the aim of systematically map the country's resources, did not 
exist. Sporadic geological work was carried out (Villalobos 1990), but it was not nearly enough to acquire complete and in-depth knowledge of existing ores, their grade and possible profits. Therefore, the several thousand mines that were abandoned and the unexploited mineral and metal deposits remained unknown. This situation endured and large ore deposits were not found until recent time (De Ferranti et al 2002, 58-59). In short, the lack of a systematic national geological survey organisation had huge implications for the progress of the mining sector by blocking the start-up of new mining projects. This, in turn, was linked to the small number of mining engineers and geologists in the country, who were indispensable for this type of work.

The underlying reasons for downgrading mining in Chile was perhaps related to the agricultural elite, which dominated the political agenda (Mahon 1992, 256). Although there were political decision-makers who saw the importance of fostering mining, the great majority of the political sphere had other interests, which possibly was in direct conflict with mining. In Norway, the decision to establish the public Survey contributed to a modernisation of copper, silver, and nickel mining and a new large-scale electro-metallurgical industry based on hydroelectric capacity (Børresen 2008).

\section{Concluding remarks}

This paper has sought to contribute to the literature about natural resource intensive industries by making a detailed comparative analysis of the performances of four comparable knowledge organisations in Chile and Norway, which aimed to develop knowledge for mining. On the surface, all the organisations appear equal, and some of them also were. However, the formation of these organisations did not guarantee development, and, as seen, the mining sector in Chile stagnated from the late nineteenth century. The mining sector in Chile was huge, but developed slowly, while the mining sector in Norway continuously changed and adapted to global trends. Why did the two sectors develop so differently when it came to mineral utilisation, technological level and integration of multinationals? The aim here has been to indicate 1) how some natural resource industries have been more dynamic and innovative than others, and 2) contributing factors to such differences. The paper suggests that innovative and dynamic mining companies at the turn of the twentieth century used complex knowledge and that innovation occurred in collaboration with a variety of organisations, such as companies, universities, schools, research centres and mining societies. Furthermore, the comparative analysis between key organisations shows that there were discrepancies in knowledge development in Chile and Norway, which indicates that there was a knowledge gap between the two countries. This knowledge gap contributes to explain the development gap between the two mining sectors. The set of organisations in Chile blocked transfer, use and diffusion of knowledge, while in Norway the organisations facilitated knowledge development. A simplified outline of the performances of the organisations is shown in Table 5 as 'weak', 'medium' and 'strong'):

Table 5. Simple overview of knowledge organisations and the knowledge gap*

\begin{tabular}{|c|c|c|c|c|c|c|}
\hline \multirow{2}{*}{\multicolumn{2}{|c|}{ Organisation }} & \multirow{3}{*}{$\begin{array}{l}\text { Variable } \\
\begin{array}{l}\text { Mining } \\
\text { instruction }\end{array}\end{array}$} & \multirow{3}{*}{$\begin{array}{l}\text { Measurement } \\
\begin{array}{l}\text { Character of } \\
\text { mining instruction }\end{array}\end{array}$} & \multicolumn{2}{|c|}{$\begin{array}{c}\text { Performance in } \\
\text { terms of } \\
\text { knowledge } \\
\text { development }\end{array}$} & \multirow[t]{2}{*}{ Comment } \\
\hline & & & & Chile & Norway & \\
\hline \multirow[b]{2}{*}{$\begin{array}{l}\text { Universities and } \\
\text { mining schools }\end{array}$} & \multirow[b]{2}{*}{$\begin{array}{l}\text { Higher mining } \\
\text { education }\end{array}$} & & & +++ & +++ & $\begin{array}{l}\text { The two mining } \\
\text { engineering programs } \\
\text { were roughly equivalent. }\end{array}$ \\
\hline & & $\begin{array}{l}\text { Number of } \\
\text { mining } \\
\text { engineers }\end{array}$ & $\begin{array}{l}\text { Mining engineer } \\
\text { graduates } \\
\text { compared to total } \\
\text { workers }\end{array}$ & + & +++ & $\begin{array}{l}\text { Chile had too few } \\
\text { mining engineers to fill } \\
\text { all managing and } \\
\text { strategic engineering } \\
\text { positions at mining } \\
\text { companies, academia } \\
\text { and research } \\
\text { organisations, while } \\
\text { Norway had plenty. }\end{array}$ \\
\hline
\end{tabular}




\begin{tabular}{|c|c|c|c|c|c|c|}
\hline & & $\begin{array}{l}\text { Number of } \\
\text { skilled } \\
\text { workers }\end{array}$ & $\begin{array}{l}\text { Debates about } \\
\text { supply and } \\
\text { demand }\end{array}$ & + & +++ & $\begin{array}{l}\text { Chile had too few skilled } \\
\text { workers; mechanics, } \\
\text { electricians, construction } \\
\text { engineers etc., while } \\
\text { Norway had plenty. }\end{array}$ \\
\hline & \multirow[b]{2}{*}{$\begin{array}{l}\text { Intermediate } \\
\text { mining education }\end{array}$} & $\begin{array}{l}\text { Mining } \\
\text { instruction }\end{array}$ & $\begin{array}{l}\text { Character of } \\
\text { mining instruction }\end{array}$ & +++ & +++ & $\begin{array}{l}\text { The mining programs at } \\
\text { the mining schools were } \\
\text { roughly equivalent. }\end{array}$ \\
\hline & & $\begin{array}{l}\text { Number of } \\
\text { mining } \\
\text { technicians }\end{array}$ & $\begin{array}{l}\text { Mining technician } \\
\text { graduates } \\
\text { compared to total } \\
\text { workers }\end{array}$ & + & +++ & $\begin{array}{l}\text { Chile had too few } \\
\text { mining technicians to fill } \\
\text { all technical positions in } \\
\text { the sector, while Norway } \\
\text { had plenty. }\end{array}$ \\
\hline \multirow[b]{3}{*}{$\begin{array}{l}\text { Organisations for } \\
\text { knowledge transfer }\end{array}$} & \multirow[t]{2}{*}{ Mining societies } & $\begin{array}{l}\text { Mining } \\
\text { journal and } \\
\text { technical } \\
\text { magazines }\end{array}$ & $\begin{array}{l}\text { Access to } \\
\text { information about } \\
\text { new technology }\end{array}$ & +++ & +++ & \multirow{2}{*}{$\begin{array}{l}\text { Engineers and } \\
\text { industrialists had access } \\
\text { to know-what of new } \\
\text { techniques, furnaces, } \\
\text { equipment etc. through } \\
\text { journals and industrial } \\
\text { exhibitions. }\end{array}$} \\
\hline & & $\begin{array}{l}\text { Industrial } \\
\text { exhibitions }\end{array}$ & $\begin{array}{l}\text { Access to } \\
\text { information about } \\
\text { new technology }\end{array}$ & +++ & +++ & \\
\hline & $\begin{array}{l}\text { Funds and } \\
\text { scholarship } \\
\text { arrangements for } \\
\text { study travels }\end{array}$ & $\begin{array}{l}\text { Study travels } \\
\text { for practical } \\
\text { learning }\end{array}$ & $\begin{array}{l}\text { Hands-on } \\
\text { experience with } \\
\text { technology }\end{array}$ & + & +++ & $\begin{array}{l}\text { Too few study trips } \\
\text { abroad hindered transfer } \\
\text { of practical knowledge } \\
\text { of foreign technology to } \\
\text { Chile, while the many } \\
\text { study trips and stays } \\
\text { abroad by mining } \\
\text { engineers from Norway } \\
\text { led to a flow of practical } \\
\text { knowledge to this } \\
\text { country. }\end{array}$ \\
\hline \multicolumn{2}{|c|}{$\begin{array}{l}\text { Organisations making geological maps and } \\
\text { ore surveys }\end{array}$} & $\begin{array}{l}\text { Organised } \\
\text { geological } \\
\text { mapping and } \\
\text { ore surveys }\end{array}$ & $\begin{array}{l}\text { Detailed maps and } \\
\text { analyses of the } \\
\text { natural resources } \\
\text { in the country }\end{array}$ & + & +++ & $\begin{array}{l}\text { Few sporadic geological } \\
\text { surveys and ore analyses } \\
\text { in Chile blocked start-up } \\
\text { of new mining projects } \\
\text { and advancement of the } \\
\text { sector, while the } \\
\text { Geological Survey in } \\
\text { Norway encouraged new } \\
\text { mining projects in } \\
\text { Norway. }\end{array}$ \\
\hline
\end{tabular}

*+=weak, ++=medium, $+++=$ strong

This knowledge gap might have been part of a wider trend in Chile and Norway. For instance, the mechanical workshops in Chile was in the process of becoming a marginal sector in the early twentieth century, while this industry in Norway had by this time developed into a 'leading branch' (Lange 1989, 17). Comparisons of these two industries, and others, might show similar knowledge gaps.

The underlying reason for the knowledge gap may be linked to the role of the state. In Chile, members of the National Mining Society, professors and engineers in Chile expressed the need for more geological surveys, more engineers and more initiatives to send engineers abroad. However, although some public initiatives were implemented, they were clearly not enough to enable widespread technological change in the sector. It is, perhaps, strange that not more was done in Chile to graduate more engineers and to learn about the existing mineral and metal deposits, considering that the country had huge mineral and metal ores and some of the largest copper deposits in the world. Despite this huge natural resource potential, mapping the country's natural resources and formal and practical education were given lower priority. In Norway, in contrast, the state was much more active in supporting knowledge development as it funded the National Geological Survey, guaranteed general schooling, financed universities, mining and technical schools and managed many of the travel scholarship arrangements. Differences in the policy towards knowledge development for mining, and general education, in the two countries 
may be related to different attitudes among the political elite. The oligarchic political elite in Chile was perhaps not as interested in facilitating industrial development as the Norwegian government. Different political approaches towards education and industrial development in the two countries may have roots back to Colonial times. Whether the institutions created during Spanish rule and the Danish colonial power differed in this respect, and whether such differences are explained by a colonial legacy, should be further explored and compared.

\section{Acknowledgements}

The author wants to express her very great appreciation to her former supervisor, Kristine Bruland and a special thanks to Keith Smith, Olav Wicken and Mary O'Sullivan for most valuable comments and suggestions. Allan Dahl Andersen, Anabel Marín and anonymous reviewers have given me highly useful responses and remarks, which have helped me greatly in the writing process of this paper.

\section{References \\ Literature}

Andersen, Allan Dahl. 2012. "Towards a new approach to natural resources and development: the role of learning, innovation and linkage dynamics". Int. J. Technological Learning, Innovation and Development, vol. 5 (3).

Andersen, Allan Dahl, Bjørn Harold Johnson, Anabel Marín, Dave Kaplan, Lilia Stubrin, Bengt-Åke Lundvall and Raphael Kaplinsky. 2015. Natural resources, Innovation and Development. Globelics Thematic Review. Aalborg University Press.

Jerez Bravo, Victor. 1950. Album Histórico de la Escuela Univ. de Minas de Copiapó 1857-1950. Santiago.

UC (Universidad de Chile) 1843-1940. Anales de la Universidad de Chile [Annals of the University of Chile]: Santiago: Universidad de Chile.

AMS (Artiummatrikler studentene) [student yearbooks]. 1855-1940. Kristiania/Oslo.

Bassøe, Bjarne. 1961. Ingeniфrmatrikkelen Norske Sivilingeniører 1901-55 med tillegg. Oslo: Teknisk Ukeblad.

Blitz, Rudolf C. 1965. "Some observation concerning the Chilean Educational System and its Relation to Economic Growth”. In Education and Economic Development, edited by C. A. Anderson and M. J. Bowman. Chicago: Frank Cass \& Co. Ltd.

Blomström, Magnus, and Patricio Meller, eds. 1991. Diverging Paths Comparing a Century of Scandinavian and Latin American Economic Development. Washington: Johns Hopkins.

DNIF and DPF (Den norske ingeniørforeigning og Den polytekniske forening) 1913-1940. Tidsskrift for bergvaesen/Tidsskrift for kemi og bergvaesen [Mining Journal] Oslo/Kristiania.

Braun, Juan Ll., Matías Braun Ll., Ignacio Briones, José Díaz B., Rolf Lüders S., and Gert Wagner H. 2000. Economía chilena 1810-1995 Estadísticas históricas. Santiago: Pontificia Universidad Católica de Chile.

Bruland, Kristine. 1998. "Skills, learning and the International Diffusion of Technology: a Perspective on Scandinavian Industrialization”. In Technological Revolutions in Europe, edited by Maxine Berg and Kristine Bruland. Cheltenham: Edward Elgar.

Børresen, Anne Kristine, and Jan Thomas Kobberrød, red. 2007. Bergingeniфrutdanning i Norge gjennom 250 år. Trondheim: Tapir akademisk forlag.

Børresen, Anne Kristine, and Astrid Wale. 2008. Kartleggerne. Trondheim: Tapir akademisk forlag.

M. Carmagnani, El desarollo industrial y subdesarrollo económico (Santiago, 1998),

Carstens, Halfdan. 2000. ... Bygger i Berge: en beretning om norsk bergverksdrift. Trondheim: Norsk bergindustriforening Den norske bergingeniørforening Tapir.

Cohen, Wesley. M. and Daniel A. Levinthal 1990. "Absorptive capacity: A new perspective on learning and innovation", Administrative Science Quarterly, Volume 35, Issue 1.

David, Paul, and Gavin Wright. 1997. "Increasing Returns and the Genesis of American Resource Abundance". Industrial and Corporate Change, vol. 6 (2).

De Ferranti, David, Guillermo E. Perry, Daniel Lederman, and William E. Maloney. 2002. From Natural Resources to the Knowledge Economy. Washington D. C: The World Bank.

Domeyko, Ignacio. 1872. 'Reseña de los trabajos de la Universidad desde 1855 hasta el presente', in Anales de la Universidad de Chile. Santiago: Universidad de Chile.

Egaña Baraona, María Loreto. 2000. La Educación Primaria Popular en el Siglo XIX en Chile. Santiago: LOM.

Engerman, Stanley L., and Kenneth L. Sokoloff. 2005. "The Evolution of Suffrage Institutions In The New World". Journal of Economic History, vol. 65 (4).

EMC (Escuela de Minas de Copiapó). 1957. Boletin Centenario Escuela de Minas de Copiapó 1857-1957. Santiago: Impr. Artes y Letras.

Gandarillas Matta, Javier. 1915. Bosquejo del estado actual de la industrial minera del cobre en el estranjero y en 
Chile. Santiago: Ed. Universo.

Hodne, Fritz and Grytten, Ola H. 2000. Norsk фkonomi i det nittende århundre. Bergen: Fagbokforlaget.

Lange, Even. 1989. Teknologi $i$ virksomhet: verkstedindustri i Norge etter 1840. Oslo: Ad notam forlag.

Lundvall, Bengt-Åke. 2010. "Post Script: Innovation System Research - Where It came From and Where It Might Go". In National Systems of Innovation, edited by Bengt-Åke Lundvall. UK: Anthem Press.

Macchiavello Varas, Santiago. 2010. El problema de la industria del cobre en Chile y sus proyecciones económicas y sociales. Santiago: Imprenta Fisca de la Penitenciaria.

Mahon, J. A. Jr .1992. 'Was Latin America too rich to prosper? Structural and political obstacles to export-led industrial growth'. Journal of Development Studies, vol. 28, issue 2, 241-263.

Mamalakis, Markos J. 1976. The growth and structure of the Chilean economy. London and New Haven: Yale University Press.

Mokyr, Joel. 2006. "Knowledge, Enlightenment, and the Industrial Revolution: Reflections on Gifts of Athena", History of Science, vol. 45 (2).

Mokyr, Joel. 2005. Gifts of Athena. Princeton and Oxford: Princeton University Press.

Musgrave, Peter William. 1967. Technical Change the Labour Force and Education. Oxford, New York: Pergamon Press.

NIT (Norges tekniske høyskole) 1911-1940. Program for studieåret... Trondhjem: Centraltrykkeriet.

North, Douglass C. 1991. "Institutions", The Journal of Economic Perspectives, vol. 5 (1).

O'Brien, Patrick. 2011. Stages in the Evolution of a Western regime for the discovery, development and diffusion of useful and relaiable knowledge, URKEW Discussion Paper No 7, London School of Economics.

O’Rourke, Kevin. H. and Jeffrey G. Williamsen. 1995. "Education, Globalization and Catch-Up: Scandinavia in the Swedish Mirror" in Scandinavian Economic History Review, 43, (3)

OCEa (Oficina Central de Estadística) 1909-1940. Anuario Estadístico Minería y Metalurgia. Santiago: Soc. Imp. y Lit. Universo.

OCEb (Oficina Central de Estadística). 1909-1940. Anuario Estadístico de la República de Chile, Educación. Santiago: Imprenta y Encuadernación Universitaria.

Ranestad, Kristin. "Multinational mining companies, employment and knowledge transfer: Chile and Norway from ca. 1870 to 1940", unpublished (manuscript ID is FBSH-2016-0204.R1).

Ranestad, Kristin. 2015. "The mining sectors in Chile and Norway from approximately 1870 to 1940: the development of a knowledge gap." PhD diss., University of Geneva.

SB (Statens bergskole). 1966. Bergskolen 100 år Jubileumsberetning 1866-1966. Trondheim.

Singer, Charles, and Trevor I. Williams. 1958a. A History of Technoloy, volume V The Late Nineteenth Century 1850 to 1900. Oxford: The Claredon Press.

Singer, Charles, and Trevor I Williams. 1958b. A History of Technology, volume IV The Industrial Revolution The Industrial Revolution 1750 to 1850. Oxford: The Claredon Press.

SNM (Sociedad Nacional de Minería) 1890-1940. Boletin de la Sociedad Nacional de Minería [Bulletin of the National Mining Society] Santiago: Sociedad Nacional de Minería.

SSB (Statistisk Sentralbyrå). 1953. Norges Officielle Statistikk, Nasjonalregnskap 1900-1929, Oslo: Statistisk Sentralbyrå.

SSB (Statistisk Sentralbyrå). 1952. Norges Offisielle Statistikk, Nasjonalregnskap 1930-1939 og 1946-1951. Oslo: Statistisk Sentralbyrå.

Solano Vega, Francisco. 1918. El Mineral de Potrerillos 1916-1918, Copiapó. Copiapó: Imprenta Progreso.

Soto Cardenas, Alejandro. 1998. Influencia británica en el salitre: origen, naturaleza y decadencia. Santiago: Edit. Universidad de Santiago de Chile.

TU (Teknisk Ukeblad) [Technical Magazine] .1983. Oslo/Kristiania: Den norske ingeniør- og arkitektforening og Den polytekniske forening.

UC (Universidad de Chile). 2003. Egresados de Ingeniería Civil de Minas Universidad de Chile 1856-2003. Fundacion de Ingenieros de Minas de la Universidad de Chile.

Villalobos, S. et al. (1990): Historia de la ingenieria en Chile. Santiago: Editorial Universitaria.

Ville, Simon and Olav Wicken (2013). "The dynamics of resource-based economic development: Evidence from Australia and Norway". Industrial and Corporate Change, 22 (5).

Wilkins, Mira. 1974. The Maturing of Multinational Enterprise: American business abroad from 1914 to 1970. Cambridge: Harvard University Press.

Yunge, Guillermo (1905). Memoria presentada por Guillermo Yunge Delegado del Gobierno de Chile a la Exposicion de Buffalo, N.Y. Santiago: Imprenta, Litografia I Encuadernacion Barcelona.

\section{Archives}

ACMCR (Anaconda Copper Mining Company Records), Montana Historical Society Archives, Collection No. 169, subj. file 6.4c, folder no. 78-6, 1925-1928 staff 